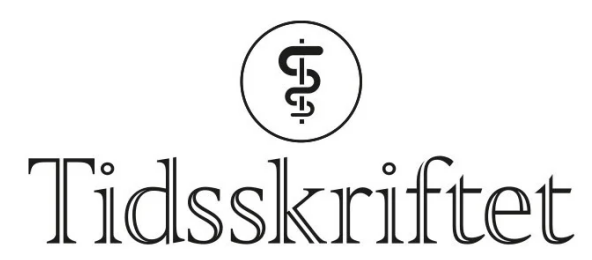

DEN NORSKE LEGEFORENING

\title{
Nye perspektiv på selvmordsforebygging
}

LEDER

\section{METTE LYBERG RASMUSSEN}

mettelybergrasmussen@gmail.com

Mette Lyberg Rasmussen er ph.d., spesialist i voksenpsykologi og psykolog i privat praksis. Forfatteren har fylt ut ICMJE-skjemaet og oppgir ingen interessekonflikter.

\section{Fraværet av effektiv forebygging av selvmord er et av våre store folkehelseproblem. Vi trenger et bredere perspektiv på selvmord enn sykdomsmodellen.}

Dagens selvmordsforebygging er i stor grad basert på en biomedisinsk sykdomsmodell (1). Ut fra det biomedisinske kunnskapssynet tenker man at selvmord handler om psykisk lidelse, at det er «sykdommen som dreper» (2). Videre har man tenkt at gjennom å diagnostisere og behandle den psykiske lidelsen, særlig depresjon, vil selvmordstallene gå ned. Tiltak i spesialisthelsetjenesten har derfor vært et viktig satsningsområde de siste tiårene (3). Til tross for arbeidet er det ingen signifikant nedgang i nasjonale selvmordsrater de siste 17 årene. I 2018 tok 674 mennesker livet sitt i Norge, 141 var menn under 35 år (4).

\section{«Å basere selvmordsforebygging ncermest enerådende på et biomedisinsk kunnskapssyn er problematisk»}

\footnotetext{
Å basere selvmordsforebygging nærmest enerådende på et biomedisinsk kunnskapssyn er problematisk. Nyere studier viser at oppimot $40 \%$ av selvmord ikke med rimelighet kan knyttes til alvorlig psykisk lidelse (5-7.). I en norsk studie fra 2018 dybdeintervjuet vi foreldre, søsken, kjærester og venner til unge menn som uventet tok livet sitt (ㅁ). Et gjennomgående funn var at det ikke hadde vært knyttet selvmordsfare til disse unge mennene i tiden før selvmordet, fordi de hadde høy mestringsevne og fravær av symptomer på alvorlig psykisk lidelse.

De etterlatte ga uttrykk for at fagpersoner som regel understreker sammenhengen mellom selvmord og psykisk lidelse når de uttaler seg i media, og at denne «antagelsen om at selvmord skyldes psykisk sykdom» hadde vært til hinder for å avdekke selvmordsfare i perioden før selvmordet. Det er et viktig innspill til selvmordsforebygging, og sier noe om
} 
at kunnskapsformidling til både befolkningen og fagpersoner kan ha vært for snevert rettet mot psykisk lidelse fremfor kunnskap om hva suicidalitet kan handle om. Dette kan også være en del av forklaringen på hvorfor selvmordstallene ikke går ned.

Ut ifra psykologisk suicidologisk teori forstås selvmordsatferd som en reaksjon på stort indre og ytre press, og selvmord oppleves av den suicidale som den eneste veien ut av en uløselig krisesituasjon (9.). Denne forståelsen gjelder enten avdøde hadde en psykisk lidelse eller ei.

I en annen analyse av selvmordene til de samme unge norske mennene som i 2018-studien inkluderte vi de avdødes avskjedsbrev. Da fant vi at de fleste selvmordskrisene ble utløst av en sterk opplevelse av mislykkethet knyttet til at alt håp om å innfri egne ambisjoner om å leve opp til idealer og forventninger om hva de skulle klare som unge menn, var ute, kombinert med sterk skam knyttet til mulig avsløring av egne mangler og svakheter $(\underline{10})$. Det var denne indre psykiske virkeligheten de ikke mestret å forholde seg til og ikke maktet å snakke om. Slik opplevde de selvmord som eneste vei ut av problemene. Selvfølgelig gjelder ikke disse funnene for alle unge menn, men de kan gi innsikt i hva en livskrise som ender med selvmord, kan handle om hos unge menn med høy mestringsevne.

«Suicidalitet må forstås i lys av livshistorien til personen det gjelder, og selvmordsatferd har ikke nødvendigvis med en psykisk lidelse å gjøre»

I disse dager legger regjeringen frem en ny handlingsplan. Den bør inkludere kunnskap om fenomenet selvmord også fra et kontekstuelt, psykologisk og psykodynamisk perspektiv: Hva handler suicidalitet om? Hvordan møte, ta imot og romme den psykiske smerten som ofte inngår i livskriser? Hvordan møte den hjelpesøkende slik at vedkommende føler seg forstått, gjenvinner håp og kommer i kontakt med sine mestringsstrategier? Lykkes man med dette, er man kanskje i posisjon til å hjelpe vedkommende til å ta tak i og jobbe med problemene som utløste livskrisen. Suicidalitet må forstås i lys av livshistorien til personen det gjelder, og selvmordsatferd har ikke nødvendigvis med en psykisk lidelse å gjøre (9.). La oss håpe regjeringens handlingsplan forholder seg også til kvalitativ forskning. Og at vi gjennom økt forståelse kan hjelpe flere, slik at tallene går ned.

\section{LITTERATUR}

1. Handlingsplan for forebygging av selvmord og selvskading 2014-2017. Oslo: Helsedirektoratet, 2014. https://www.regjeringen.no/contentassets/62bfo29bo47945c89b294f81a7676bo4/handlingsplan_selv mord_300414.pdf Lest 4.9.2020.

2. Dagsrevyen NRK. 18.11.2018 https://tv.nrk.no/serie/dagsrevyen/201811/NNFAo3111818/avspiller Lest 4.9.2020.

3. Nasjonale retningslinjer for forebygging av selvmord i psykisk helsevern. Oslo: Sosial- og helsedirektoratet, 2008.

4. Dødsårsaksregisteret. https://www.fhi.no/hn/helseregistre-og-registre/dodsarsaksregisteret/ Lest 31.8.2020.

5. Hamdi E, Price S, Qassem T et al. Suicides not in contact with mental health services: Risk indicators and determinants of referral. J Ment Health 2008; 17:398-409. [CrossRef]

6. Freuchen A. The lost years: suicide among children and young adolescents. A psychological autopsy study of suicide victims 15 years and younger 1993-2004 in Norway. Doktoravhandling. Oslo: Institutt for klinisk medisin, Universitetet i Oslo, 2013.

7. Judd F, Jackson H, Komiti A et al. The profile of suicide: changing or changeable? Soc Psychiatry Psychiatr Epidemiol 2012; 47:1-9. [PubMed][CrossRef]

8. Rasmussen ML, Dieserud G. Etterlattes erfaringer ved selvmord hos unge menn. Tidsskr Nor Legeforen 2018; 138. doi: 10.4045/tidsskr.17.0571. [PubMed][CrossRef] 
9. Shneidman E. Suicide as psychache: A clinical approach to self-destructive behavior. Northvale, NJ: J. Aronson, 1993 .

10. Rasmussen ML, Haavind H, Dieserud G. Young men, masculinities and suicide. Arch Suicide Res 2018; 22:327-43. [PubMed][CrossRef]

Publisert: 10. september 2020. Tidsskr Nor Legeforen. DOI: 10.4045/tidsskr.20.0708

Mottatt 31.8.2020, godkjent 4.9.2020.

(C) Tidsskrift for Den norske legeforening 2023. Lastet ned fra tidsskriftet.no 26. april 2023. 